\title{
The Issue of Transparency in the Financial Statements of Commercial Banks: Empirical Evidence after the Global Financial Crisis
}

\author{
Yen Bui \\ Flinders Business School, Flinders University \\ E-mail: yen.bui@flinders.edu.au
}

Received: October 27, 2011 Accepted: November 13, 2011 Published: December 1, 2011

doi:10.5296/ajfa.v3i1.1001ＵRL: http://dx.doi.org/10.5296/ajfa.v3i1.1001

The author would like to thank Mr Graham Jones, Professor Angele Cavaye and Mr Peter Lenz for their feedbacks. Special thanks go to Mr Philip Palmer for helpful comments; and Associate Professor Sarath Delpachitra for valuable inputs, support and guidance.

\begin{abstract}
The debate on the applicability of Fair Value Accounting has resurfaced after the Global Financial Crisis. This study contributes to this debate by empirically comparing the effects when the fair value changes of financial instruments disclosed in the notes are considered in the primary financial statements. The study's sample is four major Australian banks and four of the largest American banks and covers the period from 2005 to 2010. The results show that Comprehensive Income of the sample banks is extremely negatively affected by fair value changes. Shareholders' Equity is also negatively affected, although the effects are not material. These findings indicate that, from a market value perspective, the underlying performance and risks of commercial banks are not properly reflected in the financial statements. By contrast, as a consequence of high holdings of regulatory capital, fair value changes do not trigger violations of Tier 1 Capital Ratio and Total Capital Ratio. Similar results are found for American banks when capital injections from the Troubled Assets Relief Programme are excluded.
\end{abstract}

Keywords: Commercial banks, Fair value disclosures, Comprehensive income, Shareholders' equity, Regulatory capital

JEL classification: G01, G21, G28, M41, M49 


\section{Introduction}

The debate over fair value measurement of financial instruments has been going on for more than two decades, beginning simultaneously with the Savings and Loans crisis of the United States in the late 1980s. It was argued that reporting the major financial instruments, which were integral to commercial banks' core operations, at historical cost did not portray faithfully their underlying performance and risk (Enria et al., 2004; Hodder et al., 2006). During that period, the rapid development of derivative financial instruments following the deregulation of financial markets and the increase of off-balance sheet transactions provided further reasons for the improvement of accounting standards for financial instruments (FASB, 2008). The historical cost basis of financial reporting was believed to be out of step with the changes in the investment environment and in capital market practices, where financial instruments were evaluated and traded at market values (JWGSS, 2000). It was obvious that better disclosure of these complex transactions was necessary. The Statement of Financial Accounting Standards (FAS) 107, Disclosures about Fair Value of Financial Instruments, was issued in 1991 by the Financial Accounting Standards Board (FASB). This standard required disclosures of fair values of all $^{1}$ financial instruments, both assets and liabilities, recognised and not recognised in the balance sheet (FASB, 2008). In a similar move, in 1995 the International Accounting Standards Committee (IASC), now named the International Accounting Standards Board (IASB), issued International Accounting Standard (IAS) 32, Financial Instruments: Disclosure and Presentation (IASB, 2010).

Since the issuance of FAS 107, several significant accounting standards for financial instruments have been released. Derivatives were first required to be reported at fair value in 1993 by FAS 133. Fair value measurement was subsequently required for trading securities (Landsman, 2006). Notably, the accounting standard setters from major economies attempted to introduce a comprehensive fair value accounting model for financial instruments. In 2000 the Joint Working Group of Standard Setters (JWGSS) proposed a framework for the fair value measurement of all financial instruments (JWGSS, 2000). Under this framework, all fair value changes of financial instruments were to be taken to the income statement and the balance sheet (JWGSS, 2000). Nevertheless, concerns by the regulators and opposition, mainly from the banking industry, have meant that, to date, the framework has not been mandated (ABA, 2010; BIS, 2009; JWGBA, 1999; JWGBA, 2000). Consequently, accounting standards requiring fair value disclosures of financial instruments which are still reported at historical cost in the balance sheet remain effective (with amendments) in most jurisdictions.

The Global Financial Crisis (GFC) of 2008-09 rekindled the ongoing debates and controversy on fair value accounting among major regulators, accounting standard setters and the banking industry (Laux and Leuz, 2009). There has been a significant volume of literature analysing the effects of fair value accounting, with the majority of the studies focusing on the banking industry in the United States, which was at the centre of the GFC. While proponents of fair value accounting believed that fair value measurement played a very limited role () in

\footnotetext{
${ }^{1}$ The term "all” is not technically correct as “all” does not include intangible financial instruments (see Penman, 2007).
} 
the GFC, critics contended that fair value measurement significantly contributed to this financial catastrophe (Barth and Landsman, 2010; Laux and Leuz, 2010; Mala and Chand, 2011). Both the proponents and opponents argued for and against the effects of fair value accounting under the mixed-measurement framework of historical cost and fair value. Under this framework, many commercial banks still reported a significant portion of their financial instruments at historical cost (SEC, 2008). The current mixed-measurement method was therefore dominated by historical cost accounting, not fair value accounting.

In our study, we took a different approach, by analysing the effects of reporting all financial instruments at fair value. We incorporated all disclosed fair value changes on the financial statements for selected major commercial banks. We were interested in examining how important elements of the financial statements, such as comprehensive income and shareholders' equity, are affected when all the financial instruments are reported at fair value. Further, we also investigated the change in the regulatory capital ratio when all fair value disclosures are taken to the regulatory capital. The samples selected were the four major Australian banks and the four largest American banks, according to their assets at their balance dates in 2010. Our aim was to contrast two groups of major banks operating in two countries, each of which had a very different experience during the GFC. The effects of fair value measurement of all financial instruments on current accounting and prudential measures could therefore be obtained from two extreme experiences.

The remainder of this paper is set out as follows. Section 2 provides an overview of the banking industry during the GFC and the effects of fair value accounting. Section 3 discusses the basis for the research questions. Section 4 introduces the samples and basis for analysis. Section 5 analyses the results. Section 6 presents a summary and conclusion.

\section{Banking industry during the Global Financial Crisis}

Following the technology stock market crash and the recession of 2000-02, many commercial banks in the United States changed their marketing strategy and focused on the retail banking sector, which includes the subprime ${ }^{1}$ mortgage sector. Encouraged by government policies (e.g. Community Reinvestment Act), subprime mortgage lending, which was almost non-existent in 1993, had, by 2003, exceeded $20 \%$ of total residential mortgage lending (Ryan, 2008). When house prices were accelerating and debt markets were liquid, subprime mortgagors were able to secure new debts, and defaults were low. Unfortunately, because mortgagors' equity cushion gradually declined after origination, refinancing became difficult and finally impossible (Gramlich, 2007; Ryan, 2008). Credit losses from subprime mortgages and the collapse of the housing market resulted in the rapid depreciation in the prices of loans and affected other investments whose values were directly or indirectly tied to house prices. These investments include residential mortgage backed securities (RMBS), collateralized debt obligations (CDOs) and credit derivatives, among others (Ryan, 2008).

RMBS and CDO are the two subsets of asset securitizations. ${ }^{2}$ These financial instruments

\footnotetext{
${ }^{1}$ Less than highly creditworthy (Ryan, 2008).

2 Process of pooling and selling illiquid assets (Jobst, 2006).
} 
have been a major source of financing by financial institutions since the 1990s. In 2007, the securitization market was valued at US\$9.3 trillion, twice the size of the US treasury bonds (Barth and Landsman, 2010). It is believed that the growth of the securitization market significantly contributed to the growth of the credit market, which facilitated the housing boom. Because loans were securitized, banks had a tendency to establish riskier loans. When assessing bank credit risk, credit rating agencies generally did not take into account asset securitizations (Barth et al., 2010). Further, when assets were pooled, the securities were rated less risky than the individual underlying assets (Amel-Zadeh and Meeks, 2010). Due to the lack of transparency in financial reporting in this area and the complexities involved in understanding and evaluating these complex instruments, investors underestimated the risks they were taking (Barth and Landsman, 2010). Derivatives were also at the core of the GFC because they magnified the risk to which both banks and investors were exposed (Barth and Landsman, 2010). According to Allen and Carletti (2005), credit risk transfer (credit derivatives and CDO) could create problems with liquidity and increase the risk of contagion and crises in the banking and the insurance sectors. This is essentially what happened to AIG and Lehman Brothers. ${ }^{3}$

By the end of 2009, over one hundred banks in the United States had failed (FRB, 2010b). Many of them were acquired, for instance, JP Morgan Chase's acquisition of Bear Stearns and the Bank of America's purchase of Merrill Lynch. The number of banks facing difficulties identified by the Federal Deposit Insurance Corporation increased from 250 to 700. The total value of the Troubled Assets Relief Program (TARP) amounted to US\$700 billion, of which US\$400 billion was actually taken up. Nevertheless, the amount, after inflation adjustment, vastly exceeded US spending in the Second World War (FRB, 2010b; Lewis, 2009).

By contrast with the United States and many other major economies, the Australian banking system proved to be resilient during the GFC. Unlike the extensive "rescue packages" elsewhere, there were no bank bailouts in Australia (see Hawtrey, 2009 for a list of countries where capital injection were provided and banks assets were purchased). Australian banks remained profitable as their overseas counterparts suffered severe losses during the crisis (Edey, 2009). Nevertheless, in order to promote financial stability in Australia, the Australian Government introduced the Government Guaranteed Scheme for large deposits and wholesale funding. As at January 2010, the average daily guaranteed amount was A \$166 billion. The scheme was closed to new borrowings from March 2010 (Schwartz, 2011).

Housing loans accounted for the majority of total loans by banks in Australia, where mortgage lending was more conservative in practice. Housing loans were full recourse; therefore, mortgagors had a strong incentive to avoid over-commitment. Low-doc and non-conforming loans were a small part of the market (8\%), by comparison with the

\footnotetext{
${ }^{3}$ AIG wrote more than US $\$ 440$ billion of credit default swaps, the majority of which were for debts issued by Lehman Brothers. When Lehman Brothers defaulted on its huge debts, AIG did not have sufficient cash to honour its credit default swaps contracts. It was feared that, if AIG had not been "rescued" by the US Government, AIG's problems could spread to other financial institutions and triggered the collapse of the entire system (Barth and Landsman, 2010; Johnson, 2009).
} 
subprime loans (over 20\% of total residential lending value) in the United States (Edey, 2009; Ryan, 2008). Another important factor was the timing of the housing cycle. The Australian housing cycle peaked around 2002-03 and, in the few years that followed, the housing market moved into a period of correction, with softer house prices and lower lending. Therefore, Australia evaded the problems of over-pricing and over-building experienced by the United States (Edey, 2009).

Further, because of the more conservative banking model, Australian banks had less exposure to highly risky assets such derivatives and trading securities (Edey, 2009). Australian banks had maintained a culture of intermediation rather than evolving into one of securitization, with excessive risk-taking. While many overseas counterparts encountered liquidity issues, Australian banks had a more diversified and stable funding base (Hawtrey, 2009).

\subsection{Effects of fair value accounting}

Proponents of fair value accounting believe that fair value measurement provides timely information to the market and increases the relevance and transparency of financial reporting (Barth and Landsman, 2010; Mala and Chand, 2011). When there is an obligation to report the market value of assets and liabilities without delay, firms are encouraged to take prompt action to repair and strengthen their balance sheets (Ryan, 2008). Deviations from depressed markets to avoid reporting losses and impairments could decelerate corrective measures and increase fiscal costs, such as the case of the United States' Savings and Loans crisis in the 1980s (Laux and Leuz, 2009).

Opponents to fair value accounting have expressed concern that, when financial markets become irrational and depressed, reporting fair values may not be a reliable reflection of fundamental values (Laux and Leuz, 2009). Critics have also argued that fair value accounting can lead to pro-cyclicality, causing "over-pricing during boom times and exacerbating downward pressures when prices decline in illiquid markets" (Stevenson, 2011, p. 1). Distressed downward spiralling sales of assets can contribute to systemic risks among banks and possible contagion ${ }^{4}$ (Adrian and Shin, 2008; Khan, 2010). By contrast, proponents contend that it is unlikely that the current fair value reporting framework increased banks' leverage in the boom and worsened their problems during the GFC. Although distressed sales did occur ${ }^{5}$, it was not clear that these sales resulted from the application of fair value measurement (Laux and Leuz, 2010), a view further supported by Shaffer (2010). In an examination of fourteen of the largest banks in the United States, Shaffer (2010) concluded that there was little evidence of distressed selling among these banks during 2008.

From a prudential perspective, opponents to fair value accounting have contended that reporting assets and liabilities at fair value contributed to capital losses and rendered banks undercapitalised. This situation forced governments to inject vast sums of taxpayer funds into

\footnotetext{
${ }^{4}$ Contagion happens when problems of one bank spread to other banks which may lead to the failure of the whole banking system (Pais and Stork, 2010).

${ }^{5,}$ In July 2008, Merrill Lynch sold its asset-backed securities collateralized debt obligations (ABS CDO) portfolio with a face value of US\$30.6 billion at a price of US\$6.7 billion (Amel-Zadeh and Meeks, 2010).
} 
banks (Frantianni and Marchionne, 2009; also see Veron, 2008). Fair value reporting also affected the regulatory capital requirements imposed by prudential regulators, which may have forced banks to sell assets below fundamental values ${ }^{6}$ (Khan, 2010). By contrast, Shaffer (2010) found that, for large American banks in 2008, capital destruction or depletion was caused by large loan losses, trading losses and dividend payments, rather than by the reporting of assets and liabilities at fair value. The impact of the current fair value measurement framework on capital was not large enough to trigger asset sales to replenish capital and created a downward "spiralling” offload of assets.

Barth and Landman (2010) noted that the collapse of the housing market in the United States resulted in the collapse of fair values of loans. Loans were generally the largest asset group held by commercial banks. However, as allowed by the standards, loans were not reported in the primary financial statements at fair value. The proportion of banks' assets reported at fair value in the first quarter ending 31 March 2008 in a sample of 50 representative banks in the United States was only approximately 31\% (SEC, 2008). The majority of banks' assets were reported at cost, or under alternative measurement systems other than at fair value. Similarly, the proportion of banks' liabilities reported at fair value may also have been minor because deposits and debts, which are major liabilities, were still reported at historical cost. Recent research has focused on the effects of fair value accounting in the current mixed-measurement system. Under the mixed-measurement system, banks did not report all financial instruments at fair value. Therefore, a question may be asked in relation to what the effects of using fair value measurement for all financial instruments would have been during the GFC.

\section{Research questions}

From the mid-1980s, the FASB commenced working on several projects whose aim was to develop accounting standards for new financial instruments and related transactions, including disclosure standards (FASB, 2008). The first disclosure standard was issued in 1990, FAS 105, Disclosures of Information about Financial Instruments with Off-Balance Sheet Risk and Financial Instruments with Concentrations of Credit Risks. The second disclosure standard, FAS 107, Disclosures about Fair Value of Financial Instruments, was issued in 1991. Subsequently, fair value measurement in the balance sheet was required for certain types of investment securities through FAS 115 and for derivative financial instruments through FAS 133 (Landsman, 2006). Under the Accounting Standard Codification (ASC) project, in 2009 the FASB issued FAS 107-1 and APB $^{7}$ 28-1, Interim Disclosures about Fair Value of Financial Instruments, which was subsequently replaced with ASC 825-10-50-11, Financial Instruments: Fair Value of Financial Instruments. ASC 825-10-50-11 required disclosures of the fair values of financial instruments on a more regular basis (quarterly). In Australia in 1999, the Australian Accounting Standards Boards (AASB) first introduced AASB 1033, Presentation and Disclosures of Financial Instruments, which required disclosures of net fair values of all financial instruments. The rationale behind the requirement for disclosures was that fair value information was "widely used for business

\footnotetext{
${ }^{7}$ Accounting Principles Board.
} 
purposes in determining an entity's overall financial position and in making decisions about individual financial instruments” (AASB, 1999, p. 37). AASB 1033 was replaced by AASB 7, when the IASB standards were adopted in Australia in 2005. Similar to FAS 107, AASB 7 required fair value disclosures, in a comparable manner, of financial instruments that were recognised at historical cost. That is, fair value disclosures were to be presented together with the carrying amounts reported in the balance sheet.

With the introduction of FAS 107, there has been a significant volume of accounting research that has concentrated on the value-relevance ${ }^{8}$ aspect of banks' fair value disclosures. Focusing on financial institutions and particularly the banking industry, these studies investigated major classes of financial instruments, including investment securities, loans and debts (see Barth, 1994; Barth et al., 1995; Barth et al., 1996; Eccher et al., 1996; Yonetani and Katsuo, 1998). They found significant positive correlations between fair value disclosures and market-based measures such as share prices. Other researchers furthered these studies by examining the risk-relevance aspect of fair value disclosures. Their results also showed a positive relationship between fair value measures and market-based risk measures (Hodder et al., 2006). Nevertheless, it is also observed that increasing the disclosures about the fair values of financial instruments cannot be viewed as substitutes for the recognition of financial instruments in the primary financial statements (Schipper, 2007). Ahmed et al. (2006) provided evidence on how investors' valuation of derivatives differed, depending on whether these instruments were recognised or disclosed. They identified that the valuation coefficients on recognised derivatives were significant, whereas the valuation coefficients on disclosed derivatives were not significant. They concluded that FAS 133, which required recognition of all free-standing derivatives, increased the transparency of the financial statements.

Overall, it could be concluded that fair value disclosures of financial instruments are more relevant to financial reports users than are historical cost numbers. Only the fair value recognition of financial instruments in the primary financial statements, however, ensures the transparency of the financial statements (Ahmed et al., 2006; Landsman, 2006). Due to many factors, both political and technical, the major classes of financial instruments, such as investment securities, loans, debts and deposits, continue to be reported at historical cost (see ABA, 2010; Benston, 2008; Bies, 2005; Picker et al., 2009; among others for discussions). Some subclasses of these instruments are allowed to be recognised at fair value. However, because of their classification, their unrealised gains and losses may not affect reported net income (Laux and Leuz, 2009). With the historical cost measurement model still in place, banks have some leeway to strategically time their profits and losses. The issue has been raised in the literature (see Howieson and Hancock, 1995; Barth, 2004; Laux and Leuz, 2009). Timing profits or hiding losses reduces transparency of financial statements (Laux and Leuz, 2009). In the wake of the GFC, it has been argued that deviations from the recognition of assets and liabilities at market value (fair value) shielded bank managers from the scrutiny of

\footnotetext{
${ }^{8}$ Value-relevance research analyses "the association between a security price-based dependent variable and a set of accounting variables; if an accounting number is significantly related to the dependent variable, then it is value-relevant” (Beaver, 2002, p. 459).
} 
the capital market (Laux and Leuz, 2009). In that context, it would be interesting to know how important elements of financial statements such as income and shareholders' equity would change if all financial instruments were measured at fair value. Thus, we firstly investigated:

3.1 How are reported comprehensive income and shareholders' equity affected when all financial instruments are recognised at fair value in the financial statements?

Income is one of the key indicators that financial analysts use to evaluate the performance of an economic entity. This is because income or earnings per share, not cash flows, are the more important metrics frequently considered by investors (Graham et al., 2005). Although reported net income (NI) presented in the income statement is better known than comprehensive income (CI) in the statement of changes in equity, the latter, with more incorporation of fair value changes, is a more transparent measure of income. Shareholders' equity (SE) is another important financial indicator. SE is commonly used to evaluate the gearing level and the solvency of an entity. Different gearing levels have important implications for the entity’s financial stability (Brierley and Bunn, 2005).

Fair value accounting is believed to create more volatility in financial statements for commercial banks. Volatility of financial statements is of concern to entities preparing financial statements and the regulators who are in charge of the financial stability of the financial system (Barth, 2004). The more instruments are recognised at fair value, the more volatile the financial statements become (Boyer, 2007; Novoa et al., 2009; Plantin et al., 2008a, Plantin et al., 2008b). According to Hodder et al. (2006), NI is the least volatile measure of income. Full fair value income (FFVI), when all financial instruments are recognised at fair value, is the most volatile measure. CI falls between these two measures. As a partial adoption of Hodder et al.'s (2006) method, this study aims to compare these three metrics in regard to value and variation (volatility) for a new sample of banks during the GFC period. Our second research question therefore examined:

\subsection{How do net income, comprehensive income and full fair value income compare?}

Fair value accounting and its effect on regulatory capital and, consequently, the financial stability of banks have been of major concern to prudential regulators (Barth, 2004) and this topic also been a regular subject of academic research since the mid-1990s. A study by Barth et al. (1995) suggested that American banks violate regulatory capital more frequently under fair value accounting than under historical cost accounting. In Denmark, where fair value accounting was extensively used, banks' capital ratios tended to exceed the required minimum by a large extent, at approximately 38\%-50\%. Furthermore, it was also discovered that small Danish banks violated capital ratios more frequently (Bernard et al., 1995). During the GFC, critics argued that under a fair value accounting regime banks had to recognise an unjustified reduction in the fundamental economic value of assets, with a corresponding reduction in shareholders' equity. In order to maintain solvency ratios, they were forced to raise capital during depressing capital market conditions (see Frantianni and Marchionne, 2009; Veron, 2008). It is therefore interesting to examine how regulatory capital ratios (CR) would be affected if fair value recognition were applied to all financial instruments on the 
balance sheet. We investigated:

3.3 How are Tier 1 Capital Ratio and Total Capital Ratio affected when all financial instruments are recognised at fair value on the balance sheet?

\section{Samples and basis for analysis}

This is a descriptive case study. The samples are the four major Australian banks and the four largest American banks according to their assets at their balance dates in 2010 (see Table 1). The period under study is 2005-10, inclusive. The four major Australian banks held $76 \%$ of Australian banking industry resident assets (APRA $\left.{ }^{9}, 2010\right)$; the four largest American banks held $41 \%$ of the United States domestic banking assets (FRB ${ }^{10}$, 2010a; FRB, 2010c). The issue of transparency of the financial statements is more important for large banks than small banks, because, even without any adverse situations such as the GFC, large banks are already scrutinised by the capital market, the general public and the regulators.

Insert Table 1 here

The banks selected for this study are four Australian banks and four American banks. The Australian sample banks are the National Australia Bank (NAB), Commonwealth Bank Group (CBA), Westpac Banking Corporation (WBC) and Australia \& New Zealand Banking Group (ANZ). The balance date for the Australian banks was the 30 September, except for CBA, which reported on 30 June. The American sample banks are the Bank of America (BAC), Citigroup (CTG), JPMorgan Chase (JPM) and Wells Fargo (WFC). Their balance date was 31 December.

In relation to value, commercial banks report a substantial proportion of their financial instruments at historical cost. These financial instruments include loans, deposits and debts. Apart from these three major financial instruments, commercial banks also report a number of other financial instruments at historical cost. These can be investment securities or non-marketable equity investments, federal funds and securities under re-sale or re-purchase agreements. Table 2 shows the proportion of loans, deposits and debts as a percentage of total assets. The balance sheet of commercial banks was skewed toward historical cost, especially on the liabilities side.

Insert Table 2 here

Commercial banks were required to disclose the fair values of all financial instruments recognised at historical cost in the balance sheet. For loans, fair values were estimated by discounting principal and interest payments using internal credit risk and interest rate models. Fair values of deposits were estimated by discounting contractual cash flows using current market rates for instruments with similar terms and maturities. Fair values of debts were estimated by using quoted market prices or were based on current market interest rates and credit spreads for instruments with similar terms or maturities (see sample banks' financial reports during the period 2005-10).

\footnotetext{
${ }^{9}$ Australian Prudential Regulation Authority.

${ }^{10}$ Federal Reserve Board.
} 
For the purpose of this study, reported CI, SE, regulatory capital, CR, values of risk-weighted assets and gross fair value disclosures of all financial instruments reported at historical cost were retrieved from the banks' 48 financial statements and the notes to the financial statements. Gross fair value disclosures were subsequently calculated net of tax ${ }^{11}$, based on the statutory tax rates. Because CI, SE and RC were based on after-tax profits, fair value changes were also reconstructed net of tax numbers to ensure comparability. The percentage change was calculated by dividing the fair value change after tax by CI or SE. FFVI was calculated by adding the fair value change after tax to CI. The three income measures, NI, CI and FFVI, were calculated as a percentage of total average assets.

$$
\begin{aligned}
& \text { Percentage change = Fair value change after tax } / \text { CI or SE } \\
& F F V I=C I+\text { fair value change after tax } \\
& \text { NI/CI/FFVI = NI/CI/FFVI/[(beginning assets+ending assets)/2] }
\end{aligned}
$$

The mean of NI, CI and FFVI was used to determine which income type creates the highest income numbers for banks over the designated period. The standard deviation (SD) of NI, CI and FFVI was to measure the volatility level.

Regulatory capital was composed of shareholders' equity, with adjustments allowed by the relevant prudential regulator. Australian banks were required by APRA to hold as a minimum a Tier 1 Capital Ratio (T1CR) of $4 \%$ and a Total Capital Ratio (TCR) of 8\%. To be "adequately-capitalised” under the Federal Bank Regulatory Agency definitions, American banks had to hold a T1CR of at least $4 \%$ and a TCR of at least $8 \%$. To be "well-capitalised", T1CR and TCR had to be $6 \%$ and $10 \%$ respectively. The change in CR was calculated by dividing the fair value change after tax by total risk-weighted assets. The adjusted CR was computed by adding the change in CR to the reported CR.

$$
\begin{aligned}
& \text { Change in } C R=\text { Fair value change after tax / Risk-weighted assets } \\
& \text { Adjusted } C R=\text { Reported } C R+\text { Change in } C R
\end{aligned}
$$

There are two benchmarks used in this study. If an incorporation of a fair value change triggers a change of more than $10 \%$, the change is considered material. If an incorporation of a fair value change triggers a violation of the CR, the change is considered significant.

\section{Results}

\subsection{Effects on comprehensive income and shareholders' equity}

Table 3 shows the changes in A million dollars and in percentage in CI and in SE of Australian banks when fair value disclosures are taken to CI and SE. The change in any single year can be very large for some of the sample banks. NAB shows a reduction of A \$2,157 million in CI and SE in 2009. To put this number into perspective, NAB's 2009 reported NI and CI were A $\$ 4,602$ million and A $\$ 3,993$ million respectively. CBA shows an increase of A\$1,205 million in 2010. CBA's reported NI and CI in 2010 were A \$3,410

\footnotetext{
11 Australian company tax rate is $30 \%$ and American corporate tax rate is $35 \%$.
} 
million and A\$3,408 million respectively.

Insert Table 3 here

Apart from the CBA, which shows a mean increase of $6.41 \%$ in CI for the whole period of 2005-10, the other three banks experience mean decreases. The mean decrease is very material for NAB (114.96\%) and the effect can also be extreme for any single year. For example, NAB's CI decreases more than six times in 2009 (621.73\%). NAB's CI in 2009 is A \$347 million; incorporating all fair value changes effectively transforms NAB's CI into a full fair value loss of $\mathrm{A} \$ 1,810$ million.

Different banks experience different effects of fair value changes in different periods. In 2005, NAB and WBC experienced a negative change, whereas CBA experienced a positive change, and ANZ stayed almost unchanged. WBC experienced the highest reduction in CI (by 37.27\%) in 2005, ANZ in 2007 (by 10.38\%), CBA in 2008 (by 37.96\%), and NAB in 2009 (by 621.73\%).

For WBC, ANZ and CBA, the decreases are caused by the fair value changes of loans which are not offset by the fair value changes of deposits and debts. For NAB, the decrease is caused by the fair value changes of investment securities which are not offset by the fair value changes of deposits and debts. Thus, portfolio structure and quality may have played an important role in the variation of the fair values of financial instruments in any single year (see ANZ, 2007; CBA, 2008; NAB, 2009; WBC, 2005).

In contrast with the effects on CI, the effects of fair value changes on SE are not material, with a maximum value of $4.84 \%$ and a minimum value of negative $6.29 \%$.

Table 4 shows the fair value changes in US\$ million dollars and in percentage in the CI and SE for the American banks. The fair value change in any single year can be extremely large. For example, BAC shows a fair-valued reduction of US\$24,413 million in 2008. To put this number into perspective, BAC reported a net income of US\$4,008 billion and a comprehensive loss of US\$7,946 in that year. CTG shows a fair-valued increase of US\$16,640 million in 2008. During that year, CTG reported a net loss of US\$27,684 million and a comprehensive loss of US\$48,219 million.

Insert Table 4 here

For the period 2005-10, BAC and JPM show mean CI decreases of $76.50 \%$ and $200.26 \%$ respectively; and CTG and WFC show mean increases of $81.07 \%$ and $21.14 \%$ respectively. Again, the effects can be extremely large for any single year. For example, JPM shows a reduction in CI by 12 times in 2008. This is mainly due to the fair-valued decrease of loans, which is not offset by the fair-valued decrease of debts (JPM, 2009). In contrast, CTG shows an increase of nearly six times in CI for 2008. In contrast with other American banks, CTG reduced the size of its debt portfolio significantly in 2008 by comparison with 2007 and may not have needed to obtain new funds at higher market rates. In order to measure the fair values of debts, CTG discounted cash flows using market interest rates (CTG, 2009). CTG's old debt portfolio, when measured at fair value using higher market rates of 2008, may have 
been reduced significantly.

Unlike Australian banks, there are material effects on SE for several American sample banks (maximum and minimum values are $11.75 \%$ and $16.38 \%$ respectively with a count of 5).

The negative effects appear to concentrate in the GFC years of 2008-09 and to a lesser extent, in 2010. The finding is not surprising, given that the United States was at the centre of the GFC. This is in contrast to Australian banks, where negative effects can be found in any year of the period 2005-10. Thus, the effects on Australian banks may be explained by the micro environment, where portfolio structure played a more important role.

\subsection{Comparison of net income, comprehensive income and full fair value income}

Table 5 shows NI, CI and FFVI as a percentage of average total assets for the period 2005-10 for the Australian sample banks. For this period the standard deviation of FFVI is consistently highest for the four banks, followed by the standard deviation of CI and then that of NI. That indicates that FFVI is the most volatile measure of income, with $\mathrm{NI}$ the least volatile measure. CBA's FFVI varies the most, at about three times its NI (0.37\% versus $0.12 \%)$ and CI $(0.37 \%$ versus $0.13 \%)$. WBC's FFVI varies the least by comparison with its CI and NI ( $0.19 \%$ versus $0.17 \%)$.

Insert Table 5 here

In relation to the measure of centrality, for NAB, WBC and ANZ, the mean NI is highest and the mean FFVI is lowest. CBA has a FFVI which is marginally higher than its NI and CI. The difference between NAB's mean FFVI and NI is very large: $0.47 \%$ versus $0.81 \%$. NAB's FFVI is almost half its NI. Incorporation of all fair value disclosures has changed NAB's CI to a full fair value loss $(-0.28 \%)$. WBC's mean FFVI is also $22 \%$ lower than its NI $(0.78 \%$ versus $1 \%)$.

When compared with NI, which is the best-known measure of performance of commercial banks, the FFVI of three of the Australian major banks is significantly lower. The exception is CBA. FFVI creates more volatility in income over the six-year period for all four banks. It can be concluded that Australian banks can demonstrate a more favourable picture of their underlying performance to the users of financial reports by reporting NI under the mixed-measurement regime.

Consistent with the findings for Australian banks, American banks' FFVI is the most volatile measure of income during the period 2005-10 (see Table 6). CI is somewhere in the middle and NI is the least volatile. The average variation of JPM's FFVI is about three times its NI (0.94\% versus $0.31 \%)$ and more than double its CI $(0.94 \%$ versus $0.40 \%)$. The other three banks also show noticeable differences between the standard deviation of FFVI versus that of NI, and to a lesser extent, CI.

Insert Table 6 here

The mean FFVI of BAC and of WFC is materially lower than their mean NI. BAC's FFVI is about half its NI (0.37\% versus $0.71 \%)$. WFC's FFVI is about $76 \%$ of its NI $(0.92 \%$ versus 
$1.21 \%$ ). In contrast, CTG's FFVI is about $50 \%$ higher than its NI ( $0.58 \%$ versus $0.38 \%)$. JPM's FFVI is $16 \%$ higher than its NI (0.89\% versus $0.77 \%)$. For all of the sample banks, the CI numbers are closer to the NI numbers. Thus, only FFVI creates dramatic changes to the income of banks.

Incorporating fair value changes into CI exerts more negative effects on American banks than on Australian banks. CI is changed into a full fair value loss for BAC in 2009 (-0.37\%), CTG in 2010 (-0.07\%) and JPM in 2008 (-0.49\%).

\subsection{Effects on regulatory capital}

Table 7 shows the changes in CR of Australian banks when after-tax fair value disclosures are taken to shareholders' equity. Australian banks were required by APRA to hold a minimum 4\% T1CR and 8\% TCR. During the period 2005-10, Australian banks were well capitalised, with T1CR above 6.5\% and TCR above 9.5\%.

Insert Table 7 here

When fair value disclosures are incorporated, CR only decreases by a maximum value of $0.63 \%$ (NAB in 2009) and increases by a maximum value of $0.46 \%$ (CBA in 2006). Consequently, the adjusted T1CR and TCR are also above the minimum regulatory requirements. It is therefore obvious that the incorporation of all fair value disclosures into shareholders' equity does not significantly affect T1CR and TCR for Australian banks.

Table 8 shows the changes in CR of American banks after fair value adjustments. During the period 2005-10, American banks were well capitalised under the Federal Bank Regulatory Agency's definitions, including during the crisis years. Some banks achieved the high CR with the assistance of the Troubled Asset Relief Program (TARP), while other banks accomplished this without the TARP (to be discussed further below). However, all their T1CR and TCR were above $6 \%$ and $10 \%$ respectively. When fair value disclosures are taken to shareholders' equity, CR decreases by a maximum value of $1.85 \%$ for BAC in 2008 and WFC in 2009 and increases by a maximum value of $1.67 \%$ for CTG in 2008. The adjusted T1CR and TCR of American banks are all above the "well-capitalised" benchmarks. Therefore, similar to Australian banks, for American banks, the incorporation of all fair value disclosures into shareholders' equity does not significantly affect T1CR and TCR.

Insert Table 8 here

During the GFC, the American banks BAC, CTG and JPM received financial assistance from the United States Government to strengthen their capital base through the TARP. BAC raised approximately US\$15 billion in October 2008 and US\$30 billion in January 2009 through the sale of preferred stock to the United States Department of Treasury. CTG raised US\$25 billion in October 2008 and an additional US\$20 billion in December of that year. JPM and WFC both raised US\$25 billion at the end of 2008. The four banks repaid TARP in 2009 (see BAC, 2009; CTG, 2009; JPM, 2009; WFC, 2009).

Insert Table 9 here 
As per Table 9, without US Government support through TARP, the TCR and Adjusted TCR of WFC fall below the well-capitalised benchmark (minimum 10\%) but stay above the adequately-capitalised benchmark (minimum 8\%). Being much higher capitalised, the TCR and Adjusted TCR of BAC, CTG and JPM are not significantly affected. The TCR and adjusted TCR of BAC, CTG and JPM stay above the well-capitalised benchmark without TARP funds.

\section{Conclusion}

This study shows that, when fair value changes are taken to the income statement, CI decreases materially for the majority of the sample banks in both the Australian and American groups. The fair value increases in "good years" (before the GFC) do not offset the fair value decreases in "bad years" (during and after the GFC), with some banks experiencing extreme full fair value losses. Similarly, SE also decreases on average for the majority of the sample banks. However, the effects are not material.

Relatively consistent results are found when the three income measures, NI, CI and FFVI, are compared. That is, the extent by which FFVI is lower than NI is much sharper than the extent by which FFVI is higher than NI. Consistent with Hodder et al.'s (2006) findings, FFVI is the most volatile income measure during the six-year period, followed by CI; NI is the least volatile measure.

Fair value adjustments do not trigger violations of T1CR and TCR for any of the sample banks. This appears to be consistent with previous research, where small banks, not large banks, tended to violate regulatory capital ratio more frequently when fair value accounting was applied (Bernard et al., 1995). The same results are found when TARP funds are removed from the capital of American banks, except for one of the sample banks.

The findings have important implications. During a financial crisis, fair value measurement of all financial instruments have extreme negative effects on income for the majority of the sample banks, by comparison with the current mixed-measurement of fair value and historical cost. Further, fair value measurement of all financial instruments causes much higher volatility of income year after year. Given that the banks hold dominant positions in the economies in which they operate, these effects might be viewed as creating "too much noise”. The findings provide a further confirmation of the reasons for the banking industry's success in lobbying for the mixed-measurement model. This also explains why prudential regulators have continually expressed their concern over the expansion of fair value measurement for financial instruments (see BIS, 2009; FRB, 2004). Unfortunately, by avoiding "noise" through the application of the mixed-measurement regime, financial statements have also become less transparent. The underlying performance of commercial banks and the risks they take, as judged by market value benchmarks, have not been adequately reflected in the financial statements.

On the other hand, fair value adjustments of shareholders' equity did not trigger a violation of T1CR or TCR for the sample banks during the period 2005-10. This result is consistent during the crisis years of 2008-09, with or without TARP funds. It can therefore be concluded 
that, when major banks are sufficiently capitalised, which is often the case, capital ratios will not be materially affected even if all financial instruments are measured at fair value.

Since this study focuses on only a very small sample, concentrating as it does on only two countries, an avenue for future research might be an exploration of the same themes for a large representative sample of banks and for other countries.

\section{References}

Adrian, T., Shin, H. S. (2008). Liquidity and Leverage. Staff Report No. 328, Federal Reserve Bank of New York, New York.

Ahmed, A. S., Kilic, E., Lobo, G. (2006). Does Recognition versus Disclosure Matter? Evidence from Value-Relevance of Banks’ Recognized and Disclosed Derivative Financial Instruments. The Accounting Review 81, 567-588.

Allen, F., Carletti, E. (2005). Credit transfer and contagion. Journal of Monetary Economics 53, 89-111. http://dx.doi.org/10.1016/j.jmoneco.2005.10.004.

Amel-Zadeh, A., Meeks, G. (2010). Bank failure, mark-to-market and the financial crisis. Working Paper, Judge Business School, University of Cambridge, Cambridge. http://dx.doi.org/10.2308/accr.2006.81.3.567.

American Banking Association (ABA) (2010). Fair Value and Mark to Market Accounting. American Bankers Association, Washington.

Australian Accounting Standard Board (AASB) (1999). AASB 1033 Presentation and Disclosure of Financial Instruments. Australian Accounting Standards Board, Melbourne.

Australian and New Zealand Banking Group (ANZ) (2007). Financial Report 2007. Australian and New Zealand Banking Group Limited, Melbourne.

Australian Prudential Regulation Authority (APRA) (2010). APRA Insight, Issue 2. Australian Prudential Regulation Authority, Sydney.

Bank of America (BAC) (2009). Annual Financial Report 2008. Bank of America, Charlotte, North Carolina.

Bank for International Settlements (BIS) (2009). Guiding principles for the replacement of IAS 39. Basel Committee on Banking Supervision, Bank for International Settlements.

Barth, M. E. (1994). Fair value accounting: evidence from investment securities and the market valuation of banks. The Accounting Review 69, 1-25.

Barth, M. E. (2004). Chapter 25: Fair Values and Financial Statement Volatility. In: Borio, C., Hunter, W. C., Kaufman, G. G., Tsasaronis, K. The Market Discipline Across Countries and Industries. Massachussetts Institute of Technology, Cambridge, Massachussetts.

Barth, M. E., Landsman, W. R. (2010). How did Financial Reporting Contribute to the Financial Crisis? European Accounting Review, Forthcoming issue. 
Barth, M. E., Landsman, W. R., Wahlen, J. M. (1995). Fair value accounting: Effects on banks' earnings volatility, regulatory capital, and value of contractual cash flows. Journal of Banking \& Finance 19, 577-605. http://dx.doi.org/10.1016/0378-4266(94)00141-O.

Barth, M. E., Beaver, W. H., Landsman, W. R. (1996). Value-relevance of banks' fair value disclosures under SFAS No. 107. The Accounting Review 71, 513-537.

Barth, M. E., Ormazabal, G., Taylor, D. (2010). Asset securitizations and credit risk. Working Paper, Graduate School of Business, Stanford University, Stanford, California.

Beaver, W. H. (2002). Perspective on recent capital market research. The Accounting Review 77, 453-474. http://dx.doi.org/10.2308/accr.2002.77.2.453.

Benston, G. (2008). The shortcomings of fair value accounting described in SFAS 157. Journal of Accounting and Public Policy 27, 101-114. http://dx.doi.org/10.1016/j.jaccpubpol.2008.01.001.

Bernard, V. L., Merton, R. C., Palepu, K. G. (1995). Mark-to-market Accounting of Banks and Thrifts: Lessons from the Danish Experience. Journal of Accounting Research 33, 1-32. http://dx.doi.org/10.2307/2491290.

Bies, S. (2005). Fair Value Accounting. Federal Reserve Bulletin 91, 26-29.

Boyer, E. (2007). Assessing the impact of fair value upon financial crisis. Socio-Economic Review 5, 779-807. http://dx.doi.org/10.1093/ser/mwm018.

Brierley, P., Bunn, P. (2005). The determination of UK corporate capital gearing. Bank of England Quarterly Bulletin, Autumn, London.

CitiGroup (CTG) (2009). Financial Report 2008. Citigroup, New York.

Commonwealth Bank Group (CBA) (2008). Commonwealth Bank Group Financial Report 2008. Commonwealth Bank Group, Sydney.

Eccher, E. A., Ramesh, K., Thiagarajan, S. R. (1996). Fair value disclosures by banking holding companies. Journal of Accounting \& Economics 22, 79-117. http://dx.doi.org/10.1016/S0165-4101(96)00438-7.

Edey, M. (2009). Financial system developments in Australia and abroad. Retail Financial Services Forum, 19 August. Reserve Bank of Australia, Sydney.

Enria, A., Cappiello, L., Dierick, F., Grittini, S., Haralambous, A., Maddaloni, A., Molitor, P., Pires, F., Poloni, P. (2004). Fair Value Accounting and Financial Stability. Occasional Paper Series No.13, European Central Bank, Frankfurt.

Federal Reserve Board (FRB) (2004). Letter to the Chairman - Financial Accounting Standards Board Regarding Fair Value Measurement Exposure Draft, File Reference No. 1201-100, 4 October. Federal Reserve Board, Washington.

Federal Reserve Board (FRB) (2010a). Assets and Liabilities of Commercial Banks in the United States, H8, Current Release. Federal Reserve Board, Washington. 
Federal Reserve Board (FRB) (2010b). Federal Reserve Bulletin May 2010: Profits and Balance Sheet Developments at U.S. Commercial Banks in 2009. Federal Reserve Board, Washington.

Federal Reserve Board (FRB) (2010c). Large Commercial Banks, insured US chartered commercial banks that have consolidated assets of $\$ 300$ million or more, ranked by consolidated assets, as of December 31, 2009. Federal Reserve Board, Washington.

Financial Accounting Standards Board (FASB) (2008). Statement of Financial Accounting Standards No. 107: Disclosures about Fair Value of Financial Instruments. Financial Accounting Standards Board, Norwalk.

Frantianni, M., Marchionne, F. (2009). The Role of Banks in the Subprime Financial Crisis. Working Paper No. 23. Money and Finance Research Group, Universita Politecnica delle Marche, Rome and Indiana University, Indiana.

Graham, J. R., Harvey, C. R., Rajgopal, S. (2005). The economic implications of corporate financial reporting. Journal of Accounting and Economics 40, 3-73. http://dx.doi.org/10.1016/j.jacceco.2005.01.002.

Gramlich, E. M. (2007). Booms and Busts: The Case of Subprime Mortgages. Paper presented at the symposium "Housing, Housing Finance and Monetary Policy" 30 August - 2 September. Federal Reserve Bank of Kansas City, Wyoming.

Hawtrey, K. (2009). The Global Credit Crisis: Why Have Australian Banks Been So Remarkably Resilient? Agenda: a Journal of Policy Analysis and Reform 16, 95-114.

Hodder, L. D., Hopkins, P. E., Wahlen, J. M. (2006). Risk-Relevance of Fair Value Income Measures for Commercial Banks. The Accounting Review 81, 337-375. http://dx.doi.org/10.2308/accr.2006.81.2.337.

Howieson, B., Hancock, P. (1995). Accounting for risk in financial instruments. Managerial Finance 21, 26-42. http://dx.doi.org/10.1108/eb018495.

International Accounting Standards Boards (IASB) (2010). IAS 32: Financial Instruments: Presentation. International Accounting Standard Board, London.

JP Morgan Chase (JPM) (2009). Financial Report 2008. JP Morgan Chase, New York.

Jobst, A. A. (2006). Asset securitisation as a risk management and funding tool. What small firms need to know. Managerial Finance 32, 731-760. http://dx.doi.org/10.1108/03074350610681943.

Johnson, S. (2009). AIG Spins Off Units to Government. CFO Online Magazine, [created 2 March 2009; cited 14 August 2010], available from http://www.cfo.com/article.cfm/13213581?f=search.

Joint Working Group of Banking Associations (JWGBA) (1999). Accounting for Financial Instruments for Banks. Joint Working Group of Banking Associations, location. 
Joint Working Group of Banking Associations (JWGBA) (2000). Financial Instruments Issues Relating to Banks, Joint Working Group of Banking Associations, location.

Joint Working Group of Standard Setters (JWGSS) (2000). Accounting for financial instruments and similar items: invitation to comment [Financial Instruments. Joint Working Group of Standards Setters]. Australian Accounting Standards Board, Melbourne.

Khan, U. (2010). Does Fair Value Accounting Contribute to Systemic Risk in the Banking Industry? Working Paper, Columbia Business School, New York.

Landsman, W. R. (2006). Fair value accounting for financial instruments: some implications for bank regulations. Working Paper No. 209, Money and Economic Department, Bank for International Settlements, Basel.

Landsman, W. R. (2007). Is fair value accounting information relevant and reliable? Evidence from capital market research. Accounting and Business Research 37, 19-30.

Laux, C., Leuz, C. (2009). The crisis of fair value accounting: Making sense of the recent debate. Accounting, Organizations nd Society 34, 826-834. http://dx.doi.org/10.1016/j.aos.2009.04.003.

Laux, C., Leuz, C. (2010). Did Fair-Value Accounting Contribute to the Financial Crisis? Journal of Economic Perspectives 24, 93-118. http://dx.doi.org/10.1257/jep.24.1.93.

Lewis, M. K. (2009). The origins of the sub-prime crisis: Inappropriate policies, regulations, or both? Accounting Forum 33, 114-126. http://dx.doi.org/10.1016/j.accfor.2009.04.001.

Mala, R., Chand, P. (2011). Effect of the global financial crisis on accounting convergence. Journal of Accounting and Finance, Early view article published online.

National Australia Bank (NAB) (2009). National Australia Bank (NAB) Financial Report 2009. National Australia Bank, Melbourne.

Novoa, A., Scarlata, J., Sole, J. (2009). Procyclicality and Fair Value Accounting. Working Paper WP/09/39, International Monetary Fund, New York.

Pais, A., Stork, P. A. (2010). Contagion risk in the Australian banking and property sector. Journal of Banking \& Finance, Accepted Manuscript.

Penman, S. H. (2007). Financial reporting quality: is fair value a plus or a minus? Accounting and Business Research 37, 33-44.

Picker, R., Leo, K., Loftus, J., Clark, K., Wise, V. (2009). Australian Accounting Standards. 2nd edition, John Wiley \& Sons, Queensland.

Plantin, G., Sapra, H., Shin, H. S. (2008a). Fair Value Accounting and Financial Stability. Financial Stability Review, Banque de France, Paris.

Plantin, G., Sapra, H., Shin, H. S. (2008b). Marking-to-Market: Panacea or Pandora's Box? $\begin{array}{llll}\text { Journal of Accounting Research 46, } & \text { 460. }\end{array}$ http://dx.doi.org/10.1111/j.1475-679X.2008.00281.x. 
Ryan, S. G. (2008). Accounting in and for the Subprime Crisis. The Accounting Review 84, 1605-1638. http://dx.doi.org/10.2308/accr.2008.83.6.1605.

Schipper, K. (2007). Required Disclosures in Financial Reports. The Accounting Review 82, 301-326. http://dx.doi.org/10.2308/accr.2007.82.2.301.

Schwarts, C. (2011). The Australian Government Guarantee Scheme, Bulletin - March Quarter, Reserve Bank of Australia, Sydney.

Securities Exchange Commission (SEC) (2008). Report and Recommendations Pursuant to Section 133 of the Emergency Economic Stabilization Act of 2008: Study on Mark-to-Market Accounting. Office of the Chief Accountant, Division of Corporation Finance, United States Securities and Exchange Commission, Washington.

Shaffer, S. (2010). Fair value accounting: villain or innocent victim. Exploring the links between fair value accounting, bank regulatory capital and the recent financial crisis. Quantitative Analysis Unit, Federal Reserve Bank of Boston, Boston.

Stevenson, K. (2011). Financial reporting: Hearing the GFC message? What message? Journal of Accounting and Finance. Early view article published online.

Veron, N. (2008). Fair Value Accounting Is the Wrong Scapegoat for This Crisis. Revue d’Economie Financière and Risques, Bruegel Policy Contribution, Brussels.

Wells Fargo \& Company (WFC) (2009). Annual Report 2008. Wells Fargo \& Company, California.

Westpac Banking Corporation (WBC) (2005). Financial Report 2005. Westpac Banking Corporation, Sydney.

Yonetani, T., Katsuo, Y. (1998). Economic Policy Review - October, Fair Value Accounting and Regulatory Capital Requirements. Federal Reserve Board of New York, New York. 
Table 1. Sample banks' total assets in A\$ billion (Australian banks) and US\$ billion (American banks)

\begin{tabular}{|lcccccc|}
\hline Bank $^{\mathbf{1 2}}$ & $\mathbf{2 0 0 5}$ & $\mathbf{2 0 0 6}$ & $\mathbf{2 0 0 7}$ & $\mathbf{2 0 0 8}$ & $\mathbf{2 0 0 9}$ & $\mathbf{2 0 1 0}$ \\
\hline NAB & 423 & 485 & 565 & 657 & 654 & 686 \\
CBA & 337 & 369 & 425 & 488 & 620 & 646 \\
WBC & 300 & 300 & 375 & 440 & 590 & 618 \\
ANZ & 301 & 336 & 393 & 471 & 477 & 532 \\
\hline Average & 340 & 372 & 439 & 514 & 585 & 621 \\
\hline BAC & 1,292 & 1,460 & 1,716 & 1,818 & 2,223 & 2265 \\
CTG & 1,494 & 1,884 & 2,188 & 1,939 & 1,857 & 1914 \\
JPM & 1,199 & 1,352 & 1,562 & 2,175 & 2,032 & 2118 \\
WFC & 482 & 482 & 575 & 1,310 & 1,296 & 1258 \\
\hline Average & 1,117 & 1,294 & 1,510 & 1,810 & 1,852 & 1,889 \\
\hline
\end{tabular}

Source: Sample banks’ annual reports.

Table 2. Loans, deposits and debts as a percentage of total assets

\begin{tabular}{|c|c|c|c|c|}
\hline Banks & Loans & Deposits & Debts & Deposits and debts \\
\hline NAB & 56.03 & 48.99 & 13.62 & 62.61 \\
CBA & 72.35 & 52.68 & 21.64 & 74.32 \\
WBC & 75.44 & 54.80 & 22.96 & 77.77 \\
ANZ & 72.23 & 60.77 & 15.84 & 76.62 \\
N=24 & 69.01 & 54.31 & 18.52 & 72.83 \\
\hline BAC & 44.91 & 46.89 & 20.87 & 67.77 \\
CTG & 34.11 & 40.72 & 22.37 & 63.09 \\
JPM & 32.71 & 42.53 & 15.53 & 58.06 \\
WFC & 62.89 & 63.80 & 21.57 & 85.37 \\
N=24 & 43.65 & 48.49 & 20.08 & 68.57 \\
\hline
\end{tabular}

Sources: Sample banks’ annual reports.

${ }^{12}$ The banks are listed in the order of the size of their total assets as at the balance dates in 2010 . 
Table 3. Australian banks - effects on CI and SE when all fair value disclosures are taken to the financial statements (A $\$$ million dollars)

\begin{tabular}{|c|c|c|c|c|c|c|c|c|}
\hline Bank & Description & 2005 & 2006 & 2007 & 2008 & 2009 & 2010 & Mean \\
\hline \multirow[t]{3}{*}{ NAB } & Change (\$) & $-1,317$ & 599 & 687 & -575 & $-2,157$ & $-1,131$ & \\
\hline & CI (\%) & -32.99 & 10.21 & 18.53 & -31.66 & -621.73 & -32.13 & -114.96 \\
\hline & SE (\%) & -4.18 & 2.09 & 3.28 & -2.50 & -5.70 & -2.90 & -1.65 \\
\hline \multirow[t]{3}{*}{ CBA } & Change (\$) & 779.80 & 990.50 & -680.61 & -1035.86 & 452.27 & 1205.40 & \\
\hline & CI (\%) & 22.88 & 23.52 & -18.38 & -37.96 & 20.90 & 27.50 & 6.41 \\
\hline & SE (\%) & 3.44 & 4.64 & -3.98 & -5.66 & 2.05 & 4.84 & 0.89 \\
\hline \multirow[t]{3}{*}{ WBC } & Change (\$) & -1063.30 & -409.50 & -770.00 & -322.70 & -891.80 & -667.80 & \\
\hline & CI (\%) & -37.27 & -13.10 & -22.20 & -8.29 & -28.13 & -10.79 & -19.96 \\
\hline & SE (\%) & -6.29 & -2.54 & -4.32 & -1.63 & -2.44 & -1.66 & -3.15 \\
\hline \multirow[t]{3}{*}{ ANZ } & Change (\$) & 68.60 & 219.80 & -401.10 & -119.00 & -155.40 & -77.00 & \\
\hline & CI (\%) & 2.49 & 6.26 & -10.38 & -3.52 & -8.68 & -2.08 & -2.65 \\
\hline & SE (\%) & 0.35 & 1.10 & -1.82 & -0.45 & -0.48 & -0.23 & -0.25 \\
\hline \multirow[t]{6}{*}{$\mathrm{N}=24$} & CI (\%) & $\operatorname{Max}=$ & 27.50 & & $\operatorname{Min}=$ & -621.73 & & \\
\hline & & Change $>$ & $|10 \%|$ & & Count $=$ & $18 / 24$ & & \\
\hline & & Change > & $|50 \%|$ & & Count $=$ & $1 / 24$ & & \\
\hline & & Change > & $|100 \%|$ & & Count $=$ & $1 / 24$ & & \\
\hline & SE (\%) & $\operatorname{Max}=$ & 4.84 & & $\operatorname{Min}=$ & -6.29 & & \\
\hline & & Change $>$ & $|10 \%|$ & & Count $=$ & 0 & & \\
\hline
\end{tabular}


Table 4. American banks - effects on CI and SE when all fair value disclosures are taken to the financial statements, (US\$ million)

\begin{tabular}{|c|c|c|c|c|c|c|c|c|}
\hline Bank & Description & 2005 & 2006 & 2007 & 2008 & 2009 & 2010 & Mean \\
\hline \multirow[t]{3}{*}{ BAC } & Change (\$) & $-1,604$ & 1,645 & 3,479 & $-24,413$ & $-19,049$ & 163 & \\
\hline & CI (\%) & -13.74 & 7.38 & 14.60 & -307.23 & -164.88 & 4.90 & -76.50 \\
\hline & SE (\%) & -1.58 & 1.22 & 2.37 & -13.79 & -8.23 & 0.07 & -3.32 \\
\hline \multirow[t]{3}{*}{ CTG } & Change (\$) & 11,895 & 8,580 & 13,130 & 16,640 & 585 & $-14,755$ & \\
\hline & CI (\%) & 53.20 & 42.12 & 523.52 & -34.51 & 11.24 & -109.16 & 81.07 \\
\hline & SE (\%) & 10.57 & 7.16 & 11.56 & 11.75 & 0.38 & -8.90 & 5.42 \\
\hline \multirow[t]{3}{*}{ JPM } & Change (\$) & 1,300 & 1,690 & 585 & $-10,075$ & $-4,680$ & 130 & \\
\hline & CI (\%) & 16.12 & 11.56 & 3.65 & -1206.59 & -27.01 & 0.70 & -200.26 \\
\hline & SE (\%) & 1.21 & 1.46 & 0.47 & -6.04 & -2.83 & 0.07 & -0.94 \\
\hline \multirow[t]{3}{*}{ WFC } & Change (\$) & 1,483 & 629 & 948 & $-8,829$ & $-18,736$ & $-1,700$ & \\
\hline & CI (\%) & 20.08 & 7.38 & 11.18 & 178.76 & -82.92 & -7.66 & 21.14 \\
\hline & SE (\%) & 3.65 & 1.37 & 1.99 & -8.91 & -16.38 & -0.86 & -3.19 \\
\hline \multirow[t]{6}{*}{$\mathrm{N}=24$} & CI (\%) & Max & 523.52 & Min & -1206.59 & & & \\
\hline & & Change & $>|10 \%|$ & Count $=$ & $18 / 24$ & & & \\
\hline & & Change & $>|50 \%|$ & Count $=$ & $8 / 24$ & & & \\
\hline & & Change & $>|100 \%|$ & Count $=$ & $5 / 24$ & & & \\
\hline & SE (\%) & Max & 11.75 & Min & -16.38 & & & \\
\hline & & Change & $>|10 \%|$ & Count $=$ & $5 / 24$ & & & \\
\hline
\end{tabular}


Table 5. Australian banks - NI, CI and FFVI as a percentage of average total assets

\begin{tabular}{|c|c|c|c|c|c|c|c|c|c|}
\hline Bank & Income & 2005 & 2006 & 2007 & 2008 & 2009 & 2010 & Mean & SD \\
\hline \multirow{3}{*}{ NAB } & NI & 1.10 & 1.13 & 1.06 & 0.51 & 0.39 & 0.63 & 0.81 & 0.33 \\
\hline & CI & 0.96 & 1.26 & 1.01 & 0.43 & 0.05 & 0.53 & 0.71 & 0.45 \\
\hline & FFVI & 0.64 & 0.97 & 0.84 & 0.29 & -0.28 & 0.36 & 0.47 & 0.45 \\
\hline \multirow{3}{*}{ CBA } & NI & 1.06 & 1.12 & 1.13 & 1.06 & 0.86 & 0.90 & 1.02 & 0.12 \\
\hline & CI & 1.06 & 1.19 & 1.13 & 1.06 & 0.86 & 0.90 & 1.03 & 0.13 \\
\hline & FFVI & 1.30 & 1.47 & 1.09 & 0.53 & 0.67 & 1.26 & 1.05 & 0.37 \\
\hline \multirow{3}{*}{ WBC } & NI & 1.15 & 1.10 & 1.04 & 0.97 & 0.68 & 1.06 & 1.00 & 0.17 \\
\hline & CI & 1.12 & 1.10 & 1.03 & 0.96 & 0.62 & 1.02 & 0.97 & 0.19 \\
\hline & FFVI & 0.70 & 0.96 & 0.80 & 0.88 & 0.44 & 0.91 & 0.78 & 0.19 \\
\hline \multirow{3}{*}{ ANZ } & NI & 1.13 & 1.16 & 1.15 & 0.77 & 0.62 & 0.89 & 0.95 & 0.23 \\
\hline & CI & 0.99 & 1.10 & 1.06 & 0.78 & 0.38 & 0.73 & 0.84 & 0.27 \\
\hline & FFVI & 1.01 & 1.17 & 0.95 & 0.76 & 0.34 & 0.72 & 0.83 & 0.29 \\
\hline
\end{tabular}

Table 6. American banks - NI, CI and FFVI as a percentage of average total assets

\begin{tabular}{|l|l|r|r|r|r|r|r|r|r|}
\hline Bank & Income & \multicolumn{1}{c|}{$\mathbf{2 0 0 5}$} & \multicolumn{1}{c|}{$\mathbf{2 0 0 6}$} & \multicolumn{1}{c|}{$\mathbf{2 0 0 7}$} & \multicolumn{1}{c|}{$\mathbf{2 0 0 8}$} & \multicolumn{1}{c|}{$\mathbf{2 0 0 9}$} & \multicolumn{1}{c|}{$\mathbf{2 0 1 0}$} & \multicolumn{1}{c|}{ Mean } & \multicolumn{1}{c|}{ SD } \\
\hline \multirow{3}{*}{ BAC } & NI & 1.37 & 1.54 & 0.94 & 0.23 & 0.31 & -0.10 & 0.71 & 0.67 \\
& CI & 0.97 & 1.62 & 1.50 & -0.45 & 0.57 & 0.15 & 0.73 & 0.80 \\
& FFVI & 0.84 & 1.74 & 1.72 & -1.83 & -0.37 & 0.15 & 0.37 & 1.37 \\
\hline \multirow{3}{*}{ CTG } & NI & 1.65 & 1.28 & 0.18 & -1.34 & -0.08 & 0.58 & 0.38 & 1.07 \\
& CI & 1.50 & 1.21 & 0.12 & -2.34 & 0.27 & 0.72 & 0.25 & 1.37 \\
& FFVI & 2.30 & 1.71 & 0.77 & -1.53 & 0.31 & -0.07 & 0.58 & 1.36 \\
& NI & 0.72 & 1.13 & 1.05 & 0.30 & 0.56 & 0.84 & 0.77 & 0.31 \\
JPM & CI & 0.68 & 1.15 & 1.10 & 0.04 & 0.82 & 0.90 & 0.78 & 0.40 \\
& FFVI & 0.79 & 2.41 & 1.14 & -0.49 & 0.60 & 0.90 & 0.89 & 0.94 \\
\hline \multirow{3}{*}{ WFC } & NI & 1.69 & 1.76 & 1.52 & 0.28 & 0.99 & 1.01 & 1.21 & 0.56 \\
& CI & 1.62 & 1.77 & 1.60 & -0.52 & 1.77 & 1.15 & 1.23 & 0.89 \\
& FFVI & 1.95 & 1.90 & 1.78 & -1.46 & 0.30 & 1.06 & 0.92 & 1.33 \\
\hline
\end{tabular}


Table 7. Australian banks - changes in Tier 1 Capital Ratio (T1CR) and Total Capital Ratio (TCR) when fair value disclosures are taken to shareholders' equity

\begin{tabular}{|c|c|c|c|c|c|c|c|}
\hline Bank & Description & 2005 & 2006 & 2007 & 2008 & 2009 & 2010 \\
\hline \multirow[t]{5}{*}{ NAB } & T1CR & 7.50 & 7.30 & 6.70 & 7.40 & 8.96 & 8.91 \\
\hline & Adjusted T1CR & 7.07 & 7.49 & 6.89 & 7.23 & 8.33 & 8.58 \\
\hline & TCR & 10.50 & 10.80 & 10.00 & 10.90 & 11.48 & 11.36 \\
\hline & Adjusted TCR & 10.04 & 10.99 & 10.19 & 10.73 & 10.85 & 11.03 \\
\hline & CR +/- & -0.46 & 0.19 & 0.19 & -0.17 & -0.63 & -0.33 \\
\hline \multirow[t]{5}{*}{ CBA } & T1CR & 7.46 & 7.56 & 7.14 & 8.17 & 8.07 & 9.15 \\
\hline & Adjusted T1CR & 7.87 & 8.02 & 6.86 & 7.67 & 8.23 & 9.56 \\
\hline & TCR & 9.75 & 9.66 & 9.76 & 11.58 & 10.42 & 11.49 \\
\hline & Adjusted TCR & 10.16 & 10.12 & 9.48 & 11.08 & 10.58 & 11.90 \\
\hline & $\mathrm{CR}+/-$ & 0.41 & 0.46 & -0.28 & -0.50 & 0.16 & 0.41 \\
\hline \multirow[t]{5}{*}{ WBC } & T1CR & 7.20 & 6.90 & 6.50 & 7.80 & 8.10 & 9.10 \\
\hline & Adjusted T1CR & 6.58 & 6.69 & 6.16 & 7.68 & 7.79 & 8.86 \\
\hline & TCR & 9.70 & 9.60 & 9.50 & 10.80 & 10.80 & 11.00 \\
\hline & Adjusted TCR & 9.08 & 9.39 & 9.16 & 10.68 & 10.49 & 10.76 \\
\hline & $\mathrm{CR}+/-$ & -0.62 & -0.21 & -0.34 & -0.12 & -0.31 & -0.24 \\
\hline \multirow[t]{5}{*}{ ANZ } & T1CR & 6.90 & 6.80 & 6.70 & 7.70 & 10.60 & 10.10 \\
\hline & Adjusted T1CR & 6.93 & 6.89 & 6.55 & 7.66 & 10.54 & 10.07 \\
\hline & TCR & 10.50 & 10.60 & 10.10 & 11.10 & 13.70 & 11.90 \\
\hline & Adjusted TCR & 10.53 & 10.69 & 9.95 & 11.06 & 13.64 & 11.87 \\
\hline & $\mathrm{CR}+/-$ & 0.03 & 0.09 & -0.15 & -0.04 & -0.06 & -0.03 \\
\hline
\end{tabular}


Table 8. American banks - changes in Tier 1 Capital Ratio (T1CR) and Total Capital Ratio (TCR) when fair value disclosures are taken to shareholders' equity

\begin{tabular}{|c|c|c|c|c|c|c|c|}
\hline Bank & Description & 2005 & 2006 & 2007 & 2008 & 2009 & 2010 \\
\hline \multirow[t]{5}{*}{ BAC } & T1CR & 8.25 & 8.64 & 6.87 & 9.15 & 10.40 & 11.24 \\
\hline & Adjusted T1CR & 8.07 & 8.80 & 7.16 & 7.30 & 9.16 & 11.25 \\
\hline & TCR & 11.08 & 11.88 & 11.02 & 13.00 & 14.66 & 15.77 \\
\hline & Adjusted TCR & 10.90 & 12.04 & 11.31 & 11.15 & 13.42 & 15.78 \\
\hline & $\mathrm{CR}+/-$ & -0.18 & 0.16 & 0.29 & -1.85 & -1.24 & 0.01 \\
\hline \multirow[t]{5}{*}{ CTG } & T1CR & 8.79 & 8.59 & 7.12 & 11.92 & 11.67 & 12.91 \\
\hline & Adjusted T1CR & 10.13 & 9.40 & 8.17 & 13.59 & 11.72 & 11.40 \\
\hline & TCR & 12.02 & 11.65 & 10.70 & 15.70 & 15.25 & 16.59 \\
\hline & Adjusted TCR & 13.36 & 12.46 & 11.75 & 17.37 & 15.30 & 15.08 \\
\hline & $\mathrm{CR}+/-$ & 1.34 & 0.81 & 1.05 & 1.67 & 0.05 & -1.51 \\
\hline \multirow[t]{5}{*}{ JPM } & T1CR & 8.50 & 8.70 & 8.40 & 10.90 & 11.10 & 12.10 \\
\hline & Adjusted T1CR & 8.65 & 8.88 & 8.46 & 10.09 & 10.71 & 12.11 \\
\hline & TCR & 12.00 & 12.30 & 12.60 & 14.80 & 14.80 & 15.50 \\
\hline & Adjusted TCR & 12.15 & 12.48 & 12.66 & 13.99 & 14.41 & 15.51 \\
\hline & $\mathrm{CR}+/-$ & 0.15 & 0.18 & 0.06 & -0.81 & -0.39 & 0.01 \\
\hline \multirow[t]{5}{*}{ WFC } & T1CR & 8.26 & 8.95 & 7.59 & 7.84 & 9.25 & 11.16 \\
\hline & Adjusted T1CR & 8.65 & 9.10 & 7.79 & 7.04 & 7.40 & 10.99 \\
\hline & TCR & 11.64 & 12.50 & 10.68 & 11.83 & 13.26 & 15.01 \\
\hline & Adjusted TCR & 12.03 & 12.65 & 10.88 & 11.03 & 11.41 & 14.84 \\
\hline & $\mathrm{CR}+/-$ & 0.39 & 0.15 & 0.20 & -0.80 & -1.85 & -0.17 \\
\hline
\end{tabular}

Table 9. American banks - Total Capital Ratio (TCR) and Adjusted Total Capital Ratio (\%) without the support of TARP, for the year 2008

\begin{tabular}{|c|r|r|}
\hline Bank & \multicolumn{1}{|c|}{ TCR } & Adjusted TCR \\
\hline BAC & 11.86 & 10.02 \\
\hline CTG & 11.18 & 12.85 \\
\hline JPM & 12.80 & 11.99 \\
\hline WFC & 9.56 & 8.76 \\
\hline
\end{tabular}

